Volume 3 No 2 Maret 2018

p-ISSN : 2460-8750 e-ISSN : 2615-1731

http://dx.doi.org/10.26858/talenta.v3i2.6526

\title{
MOTIF PERSAHABATAN DAN KESEPIAN PADA SANTRI
}

\author{
Sulfianti Syamsul ${ }^{1}$, Widyastuti ${ }^{2}$, Muhammad Nur Hidayat Nurdin ${ }^{3}$ \\ Fakultas Psikologi Universitas Negeri Makassar \\ Email: ${ }^{1}$ sulfiantishulfy@yahoo.com ${ }^{2}$ widyastuti@unm.ac.id ${ }^{3}$ mnur.hidayat@unm.ac.id
}

(7) (8) (C2018 -JPT Fakultas Psikologi Universitas Negeri Makassar. Ini adalah artikel dengan akses terbuka dibawah licenci CC BY-NC-4.0 (https://creativecommons.org/licenses/by-nc/4.0/ ).

\begin{abstract}
Abstrack. This research aims to determine the correlation of motive for friendship towards loneliness on boarding school students. This research has 247 student subjects consisted of 172 man students and 75 woman students at the boarding school Darud Da'wah wal Irsyad Rahman Ambo Dalle Mangkoso. This research uses product moment person test. The results of this research show that was correlation of friendship motive towards loneliness $(p=0.000)$, correlation coefficient of friendship motive toward loneliness of -0.618 . The higher motive for friendship, the lower the loneliness level on boarding school students.
\end{abstract}

Keywords: boarding school, motive for friendship, loneliness.

Abstrak. Penelitian ini bertujuan untuk mengetahui hubungan antara motif persahabatan dan kesepian pada santri. Penelitian ini melibatkan 247 subjek penelitian yang terdiri atas 172 santri laki-laki dan 75 santri perempuan di pondok pesantren Darud Da'wah wal Irsyad Abdurrahman Ambo Dalle Mangkoso. Teknik analisis data dalam penelitian ini menggunakan teknik korelasi product.. Penelitian ini menunjukkan bahwa terdapat hubungan antara motif persahabatan dengan kesepian $(\mathrm{p}=0,000)$, dimana koefisien korelasi antara motif persahabatan dengan kesepian adalah sebesar -0,618. Makin tinggi skor motif persahabatan, maka makin rendah skor kesepian pada santri.

Kata Kunci: santri, motif persahabatan, kesepian

\section{PENDAHULUAN}

Santri adalah sebutan bagi peserta didik yang sedang menuntut dan mendalami ilmu keagamaan, tinggal di dalam pondok pesantren dalam rentang usia remaja (Rahmawati, 2015). Pritaningrum dan Hendriani (2013) menjelaskan bahwa santri pondok pesantren memiliki heterogenitas yang tinggi. Santri memiliki latar belakang yang berbeda, baik daerah asal, bahasa, dan ekonomi. Kewajiban untuk tinggal di pondok pesantren menuntut santri untuk berpisah dari keluarga dan belajar untuk hidup mandiri di dalam pondok pesanten.

$$
\text { Baron dan Byrne }
$$

mengemukakan bahwa perpindahan lokasi baru mengharuskan individu untuk membangun hubungan dengan orang-orang yang baru. Lingkungan sosial yang baru bagi 
remaja seperti belajar di sekolah yang baru, pindah ke kota yang baru, ataupun berpisah dari keluarga dapat menimbulkan kesepian (Sears, Freedman \& Peplau, 1985). Hal tersebut sejalan dengan yang di kemukakan oleh Indrawati dan Fauziah (2010) bahwa kesepian dapat terjadi karena perubahan lingkungan hidup, tempat tinggal, perubahan psikologis, serta kehilangan orang-orang yang bermakna.

Penelitian yang dilakukan oleh Hidayati (2015) terhadap 254 santri menjelaskan bahwa terdapat 134 santri atau $52,8 \%$ memiliki tingkat kesepian yang tinggi. Hal tersebut membuktikan bahwa lebih dari 50\% santri mengalami kesepian di pondok pesantren. Hal ini diperkuat dengan hasil pengambilan data awal yang dilakukan di salah satu pondok pesantren pada hari Kamis, 8 September 2016, dan hasilnya menyatakan bahwa dari 80 subjek penelitian, terdapat 31 santri atau $38,75 \%$ memiliki tingkat kesepian yang tinggi, 19 santri atau $23,75 \%$ memiliki tingkat kesepian yang sedang, dan 30 santri atau $37,75 \%$ memiliki tingkat kesepian yang rendah. Sehingga dapat disimpulkan bahwa dari 80 santri, terdapat 50 santri atau 62,5\% santri mengalami kesepian dengan tingkat sedang hingga tinggi.

Maghfur (2015) menjelaskan bahwa kesepian yang dialami oleh santri dikarenakan kesulitan santri dalam membangun hubungan dengan teman-teman di pondok pesantren. Santri yang mengalami kesepian akan menampilkan berbagai perilaku seperti perilaku rendah diri, agresif, melanggar peraturan, mengisolasi diri, sulit bekerja sama dalam suatu kelompok, malas belajar, dan kabur dari pesantren. Hasil penelitian yang dilakukan oleh Anggraeni (Maghfur, 2015) di SMP Islam terpadu terhadap 32 santri menunjukkan bahwa sebanyak 97\% santri pernah memiliki masalah atau perasaan negatif terhadap teman, $83 \%$ memiliki masalah dan perasaan negatif dengan peraturan, $87 \%$ santri merasa memiliki masalah dan perasaan negatif dengan guru dan pembimbing asrama, dan $67 \%$ santri menyatakan ingin kabur dari pesantren.

Butarbutar (2007) mengemukakan bahwa kesepian juga berkaitan dengan jenis kelamin. Tingkat kesepian siswa laki-laki secara signifikan lebih tinggi dari tingkat kesepian dari siswa perempuan (Tumkaya, Aybek \& Celik, 2008). Penelitian mengenai perbedaan kesepian terhadap laki-laki dan perempuan dilakukan oleh Butarbutar (2007) yang melibatkan 93 subjek, terdiri atas 52 subjek laki-laki dan 41 subjek perempuan. Penelitian tersebut menggunakan skala kesepian yang didasarkan pada teori Rubenstein, Shaver, dan Peplau. Berdasarkan hasil analisa data diperoleh nilai signifikansi $0.033(\mathrm{p}<0,05)$. Hasil penelitian tersebut membuktikan 
adanya perbedaan kesepian yang signifikan pada laki-laki dan perempuan.

Penelitian yang dilakukan oleh Mellor, Stokes, Firth, Hayashi, dan Cummins (2008) menjelaskan bahwa kegagalan untuk memenuhi kebutuhan intimasi atau keakraban dengan individu lain, dapat menyebabkan perasaan isolasi sosial, keterasingan dan kesepian. Baron dan Byrne (2005) menjelaskan bahwa cara yang paling efektif untuk terhindar dari perasaan kesepian adalah dengan mencari sahabat yang menyenangkan, pengertian, dan yang tidak sibuk dengan urusannya sendiri untuk dapat diajak berbicara, bertukar pikiran, ataupun berbagi pengalaman. Kehadiran seorang sahabat bagi remaja merupakan suatu hal yang penting, sehingga timbul motif dalam diri individu untuk menjalin suatu persahabatan (Rahmat, 2014).

Baron dan Byrne (2005) menjelaskan bahwa membangun suatu persahabatan yang sehat akan sangat bermanfaat untuk menolong individu yang mengalami kesepian. Motif persahabatan yang tinggi dapat meminimalisir kesepian yang dialami oleh santri dan sebaliknya, motif persahabatan yang rendah dapat menyebabkan kesepian yang tinggi pada santri. Semakin rendah motif persahabatan maka semakin tinggi kesepian yang dialami oleh santri. Oleh karena itu peneliti tertarik untuk meneliti lebih lanjut mengenai hubungan antara motif persahabatan dan kesepian pada santri di pondok pesantren Darud Da'wah wal Irsyad (DDI) Abdurrahman Ambo Dalle Mangkoso ditinjau dari jenis kelamin.

Berdasarkan uraian di atas, maka hipotesis dalam penelitian ini adalah ada hubungan antara motif persahabatan dengan kesepian pada santri.

\section{METODE}

Variabel bebas dalam penelitian ini adalah motif persahabatan, yakni suatu dorongan atau keinginan dalam diri individu untuk mengarahkan tingkah laku individu tersebut, untuk memperluas pergaulan dengan orang lain dan menjalin hubungan yang akrab saling percaya, menerima satu dengan yang lain, mau berbagi perasaan, pemikiran, pengalaman, serta melakukan aktivitas bersama. Variabel terikat dalam penelitian ini adalah kesepian, yakni tidak terpenuhinya kebutuhan akan hubungan dengan orang lain atau karena tidak tersedianya hubungan yang dibutuhkan individu, serta tidak memiliki seseorang yang berarti dalam suatu hubungan.

Populasi dalam penelitian ini yakni seluruh santri Pondok Pesantren Darud Da'wah Wal Irsyad Abdurrahman Ambo Dalle Mangkoso. Berdasarkan ketentuan tabel Isaac dan Michael (Sugiyono, 2009) jumlah sampel yang dianggap dapat mewakili dari 846 santri yaitu 247 santri. 
Data dikumpulkan dengan menggunakan skala. Skala yang digunakan dalam penelitian ini adalah skala motif persahabatan dari Dariyo dan Widiyanto (2013) yang mengacu pada teori yang dikemukakan oleh Gottman dan Parker (Santrock, 2007). Skala motif persahabatan terdiri dari enam aspek, yaitu: dorongan membangun pertemanan, dorongan stimulasi kompetensi, dorongan mendapat dukungan fisik, dorongan mendapat dukungan ego, dorongan mendapatkan perbandingan sosial, dan dorongan membangun intimasi. Skala kesepian merupakan adaptasi skala R-UCLA Loneliness Scale yang disusun oleh Russel yang mengacu pada aspek kesepian Weiss (Sears, Freedman \& Peplau, 1985), yaitu kesepian emosional dan kesepian sosial.

Azwar (2001) mengemukakan suatu alat ukur dapat dikatakan valid atau tidak tergantung pada kemampuan alat ukur tersebut mencapai tujuan pengukuran yang dikehendaki sebelumnya. Validitas isi yang digunakan dalam penelitian ini adalah validitas Aiken's $V$. Azwar (2015) menjelaskan bahwa Aiken's $V$ bertujuan untuk menghitung koefisien validitas isi yang didasarkan pada pendapat ahli terhadap aitem yang dapat mewakili konstrak yang diukur. Adapun hasil Aiken's $V$ pada skala motif persahabatan bergerak mulai dari 0,50 sampai dengan 0,83 . Sedangkan untuk skala kesepian bergerak mulai dari 0,58 sampai dengan 0,75 .

Azwar (2015) mengemukakan bahwa kriteria pemilihan aitem berdasarkan korelasi total yaitu 0,30 , sehingga aitem yang memiliki daya diskriminasi aitem dibawah 0,30 dinyatakan gugur. Penjelasan mengenai daya diskriminasi aitem pada skala motif persahabatan dan kesepian adalah sebagai berikut:

a. Skala motif persahabatan berdasarkan hasil uji coba menunjukkan bahwa terdapat 12 aitem yang gugur dari 40 aitem, sehingga jumlah aitem yang masih tersisa adalah 28 aitem. Aitem yang gugur adalah aitem yang memiliki koefisien validitas $<0,30$ yaitu $1,2,4,8$, 13, 20, 23, 24, 29, 35, 38, dan 40. Aitem yang valid memiliki koefisien berkisar antara 0,301 sampai dengan 0,597.

b. Skala kesepian berdasarkan hasil uji coba menunjukkan bahwa terdapat 4 aitem yang gugur dari 36 aitem yang, sehingga jumlah aitem yang masih tersisa adalah 32 aitem. Aitem yang gugur adalah aitem yang memiliki koefisien validitas $<0,30$ yaitu 6, 29, 34 dan 36. Aitem yang valid memiliki koefisien berkisar antara 0,366 sampai dengan 0,668.

Reliabilitas merupakan konsistensi dari serangkaian pengukuran atau alat ukur. Koefisien reliabilitas berada dalam rentang angka 0 sampai 1,00. Semakin koefisien mendekati angka 1,00 berarti pengukuran 
semakin reliabel. Uji reliabilitas dalam penelitian ini menggunakan alpha cronbach. Penjelasan mengenai reliabilitas kedua skala yang digunakan dalam penelitian ini dapat dilihat sebagai berikut:

a. Reliabilitas skala motif persahabatan, setelah melakukan uji coba dengan menggunakan 28 aitem dari 112 subjek, memperoleh nilai alpha sebesar 0,809. Nilai tersebut masuk dalam klasifikasi reliabilitas yang baik.

b. Reliabilitas skala kesepian, setelah melakukan uji coba dengan menggunakan 32 aitem dari 112 subjek, memperoleh nilai alpha sebesar 0,923. Nilai tersebut masuk dalam klasifikasi reliabilitas yang sangat baik.

\section{HASIL DAN PEMBAHASAN}

Subjek dalam penelitian ini adalah 247 santri pondok pesantren Darud Da'wah wal Irsyad Abdurrahman Ambo Dalle Mangkoso.

Berdasarkan hasil analisis deskriptif pada variabel motif persahabatan menunjukkan bahwa terdapat 151 santri yang memiliki tingkat motif persahabatan yang tinggi dengan persentase $61,1 \%, 95$ santri memiliki tingkat motif persahabatan yang sedang dengan persentase $38,5 \%$, dan 1 santri memiliki tingkat motif persahabatan yang rendah dengan persentase $0,40 \%$. Hasil persentase menunjukkan bahwa santri yang menjadi sampel penelitian memiliki tingkat motif persahabatan yang berada pada kategori tinggi.

Tabel 1. Kategorisasi Motif Persahabatan

\begin{tabular}{ccc}
\hline Kategori & $\mathrm{F}$ & $\mathrm{P}$ \\
\hline Tinggi & 151 & $61,1 \%$ \\
Sedang & 95 & $38,5 \%$ \\
Rendah & 1 & $0,40 \%$ \\
\hline Jumlah & 247 & $100 \%$ \\
\hline
\end{tabular}

Hasil penelitian ini sejalan dengan pendapat yang dikemukakan oleh Anas, Dewi dan Zainuddin (2015) menjelaskan bahwa salah satu bentuk interaksi sosial yang terbangun dalam dunia remaja adalah persahabatan. Persahabatan menjadi hal yang penting bagi remaja karena dengan persahabatan remaja memperoleh keakraban dan dukungan dari teman sebaya. Sahabat dapat menjadi orang yang berperan besar bagi seorang remaja tidak terkecuali santri yang berada di pondok pesantren. Desmita (2009) bahwa tinggal di lingkungan yang sama, bersekolah di sekolah yang sama, berpartisipasi dalam kegiatan organisasi yang sama merupakan faktor atau dasar utama terbentuknya motif persahabatan. Anas, Dewi dan Zainuddin (2015) menjelaskan bahwa santri di pondok pesantren bukan hanya menghabiskan waktu bersama dalam aktivitas belajar pada jam sekolah, namun juga aktivitas lain di luar jam sekolah. Aktifitas yang dilakukan secara bersama-sama dengan frekuensi yang sering akan menimbulkan kedekatan fisik. Individu yang memiliki kesempatan paling sering 
dilihat dan dijumpai memiliki peluang yang lebih besar untuk dijadikan sahabat.

Berdasarkan analisis deskriptif pada variabel kesepian menunjukkan bahwa terdapat 4 santri yang memiliki tingkat kesepian yang tinggi dengan persentase 1,6\%, 89 santri memiliki tingkat kesepian yang sedang dengan persentase 36\%, dan 154 santri memiliki tingkat kesepian yang rendah dengan persentase 62,4\%. Hasil persentase menunjukkan bahwa santri yang menjadi sampel penelitian memiliki tingkat kesepian yang berada pada kategori rendah.

Tabel 2. Kategorisasi Kesepian

\begin{tabular}{ccc}
\hline Kategori & $\mathrm{F}$ & $\mathrm{P}$ \\
\hline Tinggi & 4 & $1,6 \%$ \\
Sedang & 89 & $36 \%$ \\
Rendah & 154 & $62,4 \%$ \\
\hline Jumlah & 247 & $100 \%$ \\
\hline
\end{tabular}

Hal ini terjadi karena subjek penelitian kemungkinan besar sudah mampu beradaptasi untuk tinggal jauh dengan orang tua dan keluarga sehingga tidak lagi merasakan kesepian. Selain itu santri di pondok pesantren tidak memiliki kesenjangan antara hubungan sosial yang diinginkan dengan hubungan sosial yang dicapai, serta para santri memiliki hubungan sosial yang baik dan dinilai merasa puas dengan hubungan sosial dengan teman sebayanya sehingga santri tersebut tidak mengalami kesepian. Hal ini sejalan dengan pendapat Marx (Baron \& Byrne, 2005) mengatakan bahwa kesepian tidak terjadi jika keinginan akan kualitas dan kuantitas sebuah hubungan sesuai dengan yang diharapkan oleh individu.

Penelitian yang dilakukan oleh Mellor, Stokes, Firth, Hayashi, dan Cummins (2008) menjelaskan individu yang mampu untuk memenuhi kebutuhan intimasi atau keakraban dengan individu lain, dapat menghindarkan individu tersebut dari perasaan isolasi sosial, keterasingan dan kesepian. Penelitian ini juga menjelaskan bahwa temuan ini relevan bagi individu yang tertarik untuk memperbaiki kesulitan psikososial remaja yang mengalami kesepian.

Pengujian hipotesis dalam penelitian ini menggunakan teknik korelasi product moment dengan bantuan SPSS 23.0 for windows. Hasil pengujian hipotesis adalah sebagai berikut:

Tabel 3. Hasil Uji Hipotesis

\begin{tabular}{cccc}
\hline Variabel & $\mathrm{r}$ & $\mathrm{p}$ & Ket \\
\hline $\begin{array}{c}\text { Motif } \\
\begin{array}{c}\text { Persahabatan } \\
\text { Kesepian }\end{array}\end{array}$ & -0.618 & 0,00 & Sig. \\
\hline
\end{tabular}

Hasil analisis menunjukkan bahwa nilai koefisien korelasi antara motif persahabatan terhadap kesepian yakni sebesar $\mathrm{r}=-0,618$ dengan nilai signifikansi 0,000. Kaidah yang digunakan adalah jika signifikansi di bawah 0,05 ( $\mathrm{p}<0,05)$ maka Ha diterima dan Ho ditolak. Selain itu koefisiensi menunjukkan arah koefiseinsi korelasi sebesar -0,618 menunjukkan arah korelasi dengan hubungan negatif karena 
mendekati angka -1, sehingga dapat disimpulkan bahwa ada hubungan negatif antara motif persahabatan dengan kesepian pada santri di pondok pesantren Darud Da'wah wal Irsyad Abdurrahman Ambo Dalle Mangkoso.

Motif persahabatan berhubungan negatif terhadap kesepian, artinya semakin tinggi motif persahabatan pada santri, maka semakin rendah kesepian yang dialami oleh santri di pondok pesantren. Kehadiran seorang sahabat bagi santri di pondok pesantren merupakan suatu hal yang penting, karena sebagian besar aktifitas di lingkungan pesantren dilakukan bersamasama, sehingga timbul motif dalam diri santri untuk menjalin suatu persahabatan (Rahmat, 2014). Hasil ini sesuai dengan pendapat yang dilakukan oleh Baron dan Byrne (2005) menjelaskan bahwa membangun suatu persahabatan yang sehat akan sangat bermanfaat untuk menolong individu yang mengalami kesepian. Perlman dan Peplau (1981) menjelaskan bahwa kesepian adalah perasaan tidak menyenangkan yang berhubungan dengan ketidaksesuaian antara kebutuhan untuk akrab dengan orang lain atau keakraban personal. Namun, dalam penelitian ini mengungkapkan bahwa santri di pondok pesantren Darud Da'wah wal Irsyad Abdurrahman Ambo Dalle Mangkoso merasa puas dengan hubungan sosial serta kebutuhan untuk akrab dengan teman-teman sesama santri sehingga para santri tersebut tidak merasakan kesepian.

Baron dan Byrne (2005) menjelaskan bahwa cara yang paling efektif untuk terhindar dari perasaan kesepian adalah dengan mencari sahabat yang menyenangkan, pengertian, dan yang tidak sibuk dengan urusannya sendiri untuk dapat diajak berbicara, bertukar pikiran, ataupun berbagi pengalaman. Hasil penelitian ini juga sejalan dengan penelitian yang dilakukan oleh Mellor, Stokes, Firth, Hayashi, dan Cummins (2008) menjelaskan bahwa kegagalan untuk memenuhi kebutuhan intimasi atau keakraban dengan individu lain, dapat menyebabkan perasaan isolasi sosial, keterasingan dan kesepian.

Berdasarkan pemaparan yang dijelaskan diatas, maka peneliti menarik kesimpulan bahwa terdapat hubungan negatif antara motif persahabatan dengan kesepian karena santri di pondok pesantren. Santri di pondok pesantren Darud Da'wah wal Irsyad Abdurrahman Ambo Dalle Mangkoso mampu untuk membangun hubungan intimasi atau keakraban dengan teman-teman sesama santri, serta memiliki motif persahabatan yang tinggi sehingga kesepian yang dialami oleh santri rendah. Hal ini sesuai dengan hipotesis yang diajukan oleh peneliti bahwa semakin tinggi motif persahabatan maka semakin rendah kesepian yang dialami oleh santri. 
Selain itu, peneliti juga menguji perbedaan motif persahabatan pada santri laki-laki dan perempuan. Pengujian ini menggunakan teknik independent sample ttest dengan bantuan SPSS 23.0 for windows. Hasil dari pengujian tersebut adalah sebagai berikut:

Hasil pengolahan data berdasarkan jenis kelamin diperoleh nilai mean motif persahabatan untuk jenis kelamin laki-laki sebesar 105,37 dan besarnya standar deviasi 11,510, sedangkan untuk jenis kelamin perempuan diperoleh nilai mean 105,91 dan besarnya standar deviasi 10,537. Setelah itu, data diolah dengan menggunakan independent sample t-test untuk mengetahui perbedaan motif persahabatan berdasarkan jenis kelamin. Hasil pengolahan data menunjukkan bahwa koefisien nilai signifikansi yang diperoleh yakni 0,731. Kaidah yang digunakan adalah jika signifikansi diatas $0,05 \quad(p>0,05)$ maka hipotesis ditolak. Penelitian ini memperlihatkan bahwa tidak ada perbedaan motif persahabatan pada santri laki-laki dan santri perempuan di pondok pesantren Darud Da'wah wal Irsyad Abdurrahman Ambo Dalle Mangkoso.

Dariyo (2004) mengemukakan bahwa persahabatan merupakan hubungan antar individu yang ditandai dengan keakraban, saling percaya, menerima satu dengan yang lain, mau berbagi perasaan, pemikiran, pengalaman, serta melakukan aktivitas bersama. Oleh karena itu dapat dikatakan bahwa keinginan atau dorongan untuk menjalin hubungan yang akrab dengan orang lain secara intens dapat dikatakan sebagai motif persahabatan. Santrock (2007) menjelaskan bahwa meskipun perempuan cenderung lebih mudah membangun intimasi dalam bentuk persahabatan dan kelompok teman sebaya dibandingkan lakilaki, namun motif persahabaan atau dorongan untuk membangun hubungan dengan teman sebaya pada laki-laki tetap ada, sehingga tidak ada perbedaan antara motif persahabatan antara laki-laki dan perempuan, hanya saja perempuan lebih mudah untuk membangun intimasi dibandingkan laki-laki.

Peneliti juga mencari tahu apakah terdapat perbedaan kesepian antara laki-laki dan perempuan. Pengujian ini menggunakan teknik independent sample t-test. Hasil dari pengujian tersebut adalah sebagai berikut:

Hasil pengolahan data berdasarkan jenis kelamin diperoleh nilai mean kesepian untuk jenis kelamin laki-laki sebesar 70,03 dan besarnya standar deviasi 17,663 sedangkan untuk jenis kelamin perempuan diperoleh nilai mean 74,00 dan besarnya standar deviasi 20,675. Setelah itu, data diolah dengan menggunakan independent sample ttest untuk mengetahui perbedaan motif persahabatan berdasarkan jenis kelamin. Hasil pengolahan data menunjukkan bahwa koefisien nilai signifikansi yang diperoleh 
yakni 0,150. Kaidah yang digunakan adalah jika signifikansi diatas 0,05 ( $p>0,05)$ maka hipotesis ditolak. Penelitian ini memperlihatkan bahwa tidak ada perbedaan kesepian pada santri laki-laki dan santri perempuan di pondok pesantren Darud Da'wah wal Irsyad Abdurrahman Ambo Dalle Mangkoso.

Hasil penelitian ini sejalan dengan penelitian yang dilakukan oleh Neto (2014) yang melibatkan 3.114 subjek, yang terdiri dari 1.118 subjek laki-laki dan 2026 subjek perempuan. Hasil penelitian menunjukkan bahwa nilai $\mathrm{p}=0,84 \quad(\mathrm{p}>0,05) \quad$ sehingga menunjukkan bahwa tidak ada perbedaan kesepian berdasarkan jenis kelamin. Jenis kelamin tidak berkonstribusi terhadap kesepian yang dialami oleh individu.

Selain dua temuan tambahan di atas, peneliti juga memperoleh temuan lain dalam penelitian ini, yaitu:

a. Hasil analisis menunjukkan bahwa tidak ada perbedaan yang signifikan untuk motif persahabatan setiap tingkatan santri di pondok pesantren Darud Da'wah wal Irsyad Abdurrahman Ambo Dalle Mangkoso. Namun jika dilihat berdasarkan nilai mean yang diperoleh untuk santri laki-laki tingkatan Iddadiyah memiliki nilai mean paling rendah yaitu 103,86, yang menunjukkan bahwa diantara keseluruhan tingkatan santri laki-laki yang ada, tingkatan Iddadiyah yang memiliki motif persahabatan rendah diantara tingkatan yang lain.
Sedangkan untuk santri perempuan tingkatan kelas 3 memiliki nilai mean paling rendah yaitu 102,71, yang menunjukkan bahwa diantara keseluruhan tingkatan yang santri perempuan yang ada, tingkatan kelas 3 yang memiliki motif persahabatan rendah diantara tingkatan yang lain.

Motif persahabatan yang rendah pada santri laki-laki Iddadiyah sejalan dengan hasil penelitian yang dilakukan oleh Rahmawati (2015) terhadap 40 santri lakilaki dan 40 santri perempuan. Penelitian tersebut menyatakan bahwa santri laki-laki pada tingkatan awal atau santri baru masih belum dapat membangun persahabatan dengan sempurna karena masih memiliki ketegangan emosi yang ditandai dengan sikap waspada, malu bertanya, serta malu membangun komunikasi dengan teman yang baru dikenal, sedangkan santri perempuan pada tingkatan awal akan lebih mudah untuk membangun keintiman dan membangun komunikasi dengan teman-teman sesama santri.

Hasil penelitian ini juga mengungkapkan bahwa motif persahabatan yang rendah pada santri perempuan kelas 3 sejalan dengan hasil yang dilakukan oleh Mjaavatn dan Frostad (2016) terhadap 123 siswa yang terdiri dari 64 perempuan dan 59 laki-laki, hasil penelitian tersebut menjelaskan bahwa perempuan rentan untuk mengalami kejenuhan dalam sebuah hubungan persahabatan dibandingkan laki-laki. Sears, 
61 I Jurnal Psikologi Talenta Vol 3 No. 2

Freedman, dan Peplau

mengungkapkan bahwa pertemuan berulang yang terlalu banyak menimbulkan kejemuan dan kejenuhan. Peneliti berasumsi bahwa motif persahabatan yang rendah pada santri perempuan kelas 3 dikarenakan kejenuhan terhadap persahabatan yang dimiliki, karena santri harus bertemu dengan sahabatnya setiap hari, di tempat yang sama dan dengan situasi yang dominan sama, sehingga hal tersebut memengaruhi motif persahabatan pada santri perempuan di pondok pesantren Darud Da'wah wal Irsyad Abdurrahman Ambo Dalle Mangkoso.

b. Hasil analisis menunjukkan bahwa tidak ada perbedaan yang terlalu signifikan kesepian santri laki-laki dan perempuan setiap tingkatan di pondok pesantren Darud Da'wah wal Irsyad Abdurrahman Ambo Dalle Mangkoso. Namun jika dilihat berdasarkan nilai mean yang diperoleh untuk santri laki-laki tingkatan Iddadiyah memiliki nilai mean paling tinggi yaitu 73,61 , yang menunjukkan bahwa diantara keseluruhan tingkatan santri laki-laki yang ada, tingkatan Iddadiyah yang memiliki kesipan paling tinggi diantara tingkatan yang lain. Sedangkan untuk santri perempuan tingkatan kelas 3 memiliki nilai mean paling tinggi yaitu 78,56, yang menunjukkan bahwa diantara keseluruhan tingkatan yang santri perempuan yang ada, tingkatan kelas 3 yang memiliki kesepian tinggi diantara tingkatan yang lain.
Motif Persahabatan dan Kesepian pada Santri

Kesepian yang tinggi pada santri laki-laki Iddadiyah ini sejalan dengan pendapat yang dikemukakan oleh Indrawati dan Fauziah (2010) yang menjelaskan bahwa santri tahun pertama merupakan usia yang paling berisiko tinggi dibanding tingkat usia lain dalam mengalami kesepian. Sebuah penelitian menjelaskan bahwa sekitar $75 \%$ siswa baru mengalami kesepian, sesaat sejak masuk di sekolah baru, dan lebih dari $40 \%$ menyatakan bahwa mengalami kesepian dengan intensitas sedang sampai hebat (Sears, Freedman \& Peplau, 1985). Hal tersebut sejalan dengan hasil wawancara yang dilakukan terhadap salah satu sanri baru laki-laki di di pondok pesantren Darud Da'wah wal Irsyad Abdurrahman Ambo Dalle Mangkoso. Subjek menyatakan bahwa dirinya sangat merasa kesepian berada di pondok pesantren, subjek tidak menyenangi semua kegiatan yang ada di pondok pesantren, serta mengaku bahwa tidak ada seorangpun yang peduli dengan dirinya.

Hasil penelitian ini juga mengungkapkan bahwa kesepian yang tinggi pada santri perempuan kelas 3 sejalan dengan penelitian yang dilakukan oleh Borys dan Perlman (1985) yang melibatkan 117 subjek terdiri dari 48 subjek perempuan dan 69 subjek laki-laki dengan rentang usia 13-18 tahun, menjelaskan bahwa subjek 
perempuan pada usia tersebut lebih cenderung untuk mengaku kesepian dibandingkan laki-laki, hal ini dikarenakan konsekuensi untuk mengakui keadaan kesepian pada perempuan lebih rendah dibandingkan laki-laki. Selain itu bagi perempuan, menunjukkan perasaan kesepian merupakan suatu hal yang wajar dialami oleh individu, namun bagi laki-laki menunjukkan perasaan kesepian merupakan suatu hal kurang wajar dan berhubungan dengan maskulin.

\section{SIMPULAN DAN SARAN}

Penelitian ini menyimpulkan bahwa terdapat ada hubungan negatif antara motif persahabatan dengan kesepian pada santri di pondok pesantren Darud Da'wah wal Irsyad Abdurrahman Ambo Dalle Mangkoso. Hal ini berarti bahwa semakin tinggi motif persahabatan maka semakin rendah kesepian pada santri santri di pondok pesantren.

Peneliti mengajukan saran sebagai berikut:

a. Kepada pihak pesantren disarankan untuk melakukan kegiatan-kegiatan yang dapat lebih meningkatkan motif persahabatan pada santri guna meminimalisir kesepian yang dialami oleh santri, utamanya santri baru.

b. Bagi santri yang memiliki motif persahabatan yang rendah, perlu menumbuhkan perasaan positif terkait persahabatan, sehingga keinginan untuk membangun persahabatan dapat meningkat dan kesepian dapat diminimalisir.

c. Peneliti selanjutnya disarankan untuk memperhatikan faktor-faktor penyebab kesepian pada santri, seperti faktor situasional serta faktor personal.

\section{DAFTAR RUJUKAN}

Anas, R., Dewi, E. M., \& Zainuddin, K. (2015). Kualitas Persahabatan Siswa SMA Boarding School dan Siswa SMA Formal. Jurnal Psikologi \& Kemanusiaan Fakultas Psikologi Universitas Negeri Makassar, 1-6.

Azwar, S. (2001). Reliabilitas dan Validitas. Yogyakarta : Pustaka Pelajar Offset

Azwar, S. (2015). Penyusunan Skala Psikologi. Yogjakarta: Pustaka Pelajar Offset

Baron, R.A., \& Byrne, D. (2005). Psikologi Sosial. Jilid 2, Edisi ke-10. (R. Juwita, dkk., Penerjemah). Erlangga, Jakarta

Butarbutar, F. A. (2007). Perbedaan kesepian pada narapidana laki-laki dan perempuan. Program Studi Psikologi Fakultas Kedokteran Universitas Sumatra Utara. Skripsi. Sumatra: Diterbitkan

Borys, S., \& Perlman, D. (1985). Gender Differences in Loneliness. Society for Personality and Social Psychology , 11 (1), 63-74.

Dariyo, A. (2004). Psikologi perkembangan remaja. Bogor Selatan: GHALIA INDONESIA.

Dariyo, A., \& Widiyanto, M. A. (2013). Pengaruh Kesepian, Motif Persahabatan, Komunikasi On Line dan Terhadap Penggunaan Internet Kompulsif pada Remaja. Jurnal Psikologi , 11, 45-53. 
Desmita. (2009) Psikologi Perkembangan Peserta Didik. Bandung: PT. Remaja Rosdakarya

Hidayati, D. S. (2015). Self Compassion dan Loneliness. Jurnal Ilmiah Psikologi Terapan, 3 (1), 154-164.

Indrawati, E. S., \& Fauziah, N. (2010). Penyesuaian Sosial dan Tingkat Kesepian Mahasiswa Tahun Pertama Fakultas Psikologi UNDIP. Jurnal Psikologi Universitas Dipenegoro , 137.

Maghfur, S. (2015). Bimbingan Kelompok Berbasis Islam Untuk Meningkatkan Penyesuaian diri Santri Pondok Pesantren Al Ishlah Darussalam Semarang. Tesis.. Yogyakarta: Pasca Sarjana UIN Sunan Kalijaga.

Mellor, D., Stokes, M., Firth, L., Hayashi, Y., \& Cummins, R. (2008). Need for belonging, relationship satisfaction, loneliness, and life satisfaction. Personality and Individual Differences, 45(2008), 213-218.

Neto, F. (2014). Socio-Demographic Predictors of Loneliness Across the Adult Life Span in Portugal. An International Journal on Personal Relationships . 8(2), 222-230, DOI:10.5964/IJPR.V8I2.171

Perlman, D., \& Peplau, L. A. (1981). Toward a Social Psychology of Loneliness. In S. Duck, \& R. Gilmour, Personal Relationship in Disorder (pp. 31-56). London: Academi Press.

Pritaningrum, M., \& Hendriani, W. (2013). Penyesuaian Diri Remaja yang Tinggal di Pondok PesantrenModern Nurul Izzah Gresik Pada Tahun Pertama. Jurnal Psikologi Kepribadian dan Sosial , 2 (3), 134-143.

Rahmat, W. (2014). Pengaruh Tipe Kepribadian dan Kualitas Persahabatan dengan Kepercayaan Pada Remaja akhir. ejournal.psikologi.fisipunmul.org, 2 (2), 206-216.

Rahmawati, A. N. (2015). Kepatuahan santri terhadap aturan di pondok pesantren modern. Tesis. Surakarta: Pasca Sarjana Universitas Negeri Surakarta.
Santrock, J. W. (2007). Adolesence: Perkembangan Remaja (edisi ke-11). Jakarta: Erlangga.

Sugiyono. (2009). Metode Penelitian Kuantitatif, Kualitatuf dan $R \& D$. Bandung: CV ALFABETA.

Sears, D. O., Freedman, J. L., \& Peplau, L. A. (1985). Psikologi Sosial Jilid 1. Jakarta: Erlangga.

Tumkaya, S., Aybek, B., \& Celik, M. (2008). An investigation of students' life satisfaction and loneliness level in a sample of Turkish students ${ }^{1}$. International Journal of Human Sciences , 5 (1), 1-15. 